\title{
Tennis Coaches' Perceptions of Covid-19 Impact on Their Health and Professional Activity: A Multi-Cultural Approach
}

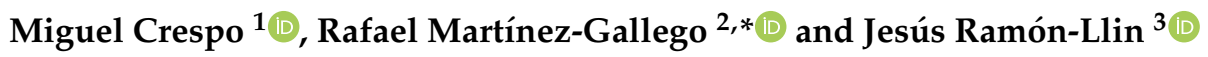 \\ 1 International Tennis Federation, London SW15 5XZ, UK; miguel.crespo@itftennis.com \\ 2 Department of Sport and Physical Education, University of Valencia, 46010 Valencia, Spain \\ 3 Department of Teaching of Music, Visual and Corporal Expression, University of Valencia, \\ 46010 Valencia, Spain; jesus.ramon@uv.es \\ * Correspondence: rafael.martinez-gallego@uv.es
}

check for

updates

Citation: Crespo, M.;

Martínez-Gallego, R.; Ramón-Llin, J.

Tennis Coaches' Perceptions of

Covid-19 Impact on Their Health and

Professional Activity: A Multi-Cultural

Approach. Sustainability 2021, 13, 5554.

https://doi.org/10.3390/su13105554

Academic Editors:

Fernando Lera-Lopez,

Themistocles Kokolakakis and

Girish Ramchandani

Received: 22 April 2021

Accepted: 15 May 2021

Published: 16 May 2021

Publisher's Note: MDPI stays neutral with regard to jurisdictional claims in published maps and institutional affiliations.

Copyright: (c) 2021 by the authors. Licensee MDPI, Basel, Switzerland. This article is an open access article distributed under the terms and conditions of the Creative Commons Attribution (CC BY) license (https:/ / creativecommons.org/licenses/by/ $4.0 /)$.

\begin{abstract}
Tennis coaches are facing considerable challenges as the game is disrupted by the COVID-19 pandemic. The long tradition of tennis in the Latin American region and in Spanish- and Portuguesespeaking European countries makes comparing these regions particularly interesting. The purpose of this research was to study the perceptions of Spanish- and Portuguese-speaking tennis coaches working in Latin American and European countries regarding the impacts of the COVID-19 pandemic on their health, professional, and economic circumstances. The perceptions of 655 coaches from 19 Latin American and European countries were collected using an ad-hoc questionnaire. Coaches reported on the incidence of the virus in terms of infection and quarantine, the impact on their coaching programs, and on their professional development, training, and education. They were also asked about their perception of the overall situation as a threat. The results showed that the COVID-19 pandemic has had a considerable impact on the health and the profession of tennis coaches. Although Latin American coaches reported a greater impact on their health, economic, and professional circumstances, they viewed the pandemic as an opportunity for professional improvement and training as compared to the perceptions of European coaches. In light of these results, implications, practical applications, and future research are proposed.
\end{abstract}

Keywords: pandemic; coaches; tennis

\section{Introduction}

The global crisis created by the ongoing COVID-19 pandemic is unprecedented. As we approach the second half of 2021, globally, as of 6:23 p.m. CEST, 2 April 2021, there have been 129,215,179 confirmed cases of COVID-19, including 2,820,098 deaths, reported. A total of 547,727,346 vaccine doses have been administered [1].

Indeed, COVID-19 has affected all aspects of human existence, including sports. As International Olympic Comitee (IOC) President Thomas Bach stated at the beginning of this period: "With the global COVID-19 pandemic, we are all living in much uncertainty. At this point in time, this uncertainty is far from subsiding (...). This new situation will need all our solidarity, creativity, determination, and flexibility. We shall all need to make sacrifices and compromises. Extraordinary circumstances call for extraordinary measures. This situation requires every one of us to do our part, and this applies to all of us, including the IOC" [2].

All sports are being affected in various ways, depending on their particular characteristics. The tennis community is also facing considerable challenges and risks as tennis is disrupted by COVID-19. Tennis is one of the most popular sports in the world. With more than 87 million players in over 200 nations, tennis is a lifetime activity that is enjoyed by people of all ages, physical abilities, and skill levels [3]. Within tennis, the pandemic has affected players, fans, event organizers, coaches, and organizations who have tried to adapt and react to these new circumstances. 


\subsection{Coaches and COVID-19}

In this scenario, coaches are one of the main stakeholders of any sport. Interestingly enough, very few studies have investigated the potential impact of the pandemic on sport coaches [4-8] and none on the perception of tennis coaches regarding the pandemic and the measures taken by the different organizations. As Faraji et al. indicated: "coaches are potentially neglected populations that have likewise been particularly affected by the shutdown, given the difficulty in carrying out their profession" [5]. Therefore, in light of the societal, economical, and professional consequences of the COVID-19 pandemic due to the postponement of coaching activity, the views of such relevant members of the sport ecosystem are felt to be crucial in facilitating understanding regarding the delivery of coaching activities in the case of tennis.

Many coaches have seen their income reduced or even have lost their employment as a consequence of the overall measures taken to reduce the impact of the pandemic, such as the closing of borders, the limitation of travel, and the shutting down of transport, services, industry, and economic activity [9]. In the case of sport and tennis, the postponement or cancellation of competitions, programs, and the closing down of venues has negatively impacted many coaches who have seen that, as Evans et al. stated: "evidence about the long-term impact of the virus on sport is only now beginning to emerge" [4].

\subsection{Tennis and COVID-19}

The global COVID-19 outbreak has certainly had a significant impact on tennis. Movement restrictions imposed by governments have resulted in the suspension of the international tennis calendar as well as of any tennis activity at different levels. As these restrictions are relaxed, it may be possible to organize tennis programs and competitions again with or, as is most likely in the short term at least, without spectators. In the specific case of tennis, there have been calls to position the sport as one of the preferred options for the return to physical activity. Due to its special characteristics as an individual non-contact sport and the fact that it respects social distancing measures, it has been presented as a safe way of exercising in these circumstances [9].

From an international perspective, the International Tennis Federation (ITF) published the "ITF Return to Tennis Guidance and Protocols" which provided stakeholders with a framework upon which to base any moves forward with the organization of international and national tournaments. The primary aim of the document was to set guidelines for minimum and recommended standards for the organization of tennis competitions. The document was developed in accordance with the WHO guidelines on the organization of sports events and with input from the Chair of the ITF Sport Science \& Medicine Commission. It was intended to supplement the existing organizational requirements for ITF events, rather than substitute for them [10].

In terms of research related to tennis and the pandemic, there have been a few studies that have analyzed the specific features of the effects of COVID-19 on the tennis industry. Most of them have focused on the impact at the professional level of the game [11-13], one evaluated children and adolescents [14] and another one focused on seniors [15]. Two studies analyzed coach-player relationships [16,17], and however none have thus far investigated the impact of the pandemic on coaches. Furthermore, several book chapters have also covered the impact of COVID-19 on the tennis ecosystem. Bradbury and Galloway [18] discussed perspectives in New Zealand, and Slater and Watkins [19] analyzed tennis players' responses to the global pandemic's impact on professional tennis governance.

To the authors' knowledge, and as can be concluded from the paragraphs above, no research so far has studied the views of tennis coaches regarding the health and professional impacts of the COVID-19 pandemic. It was thought that, given the key role coaches play in the delivery of tennis and sport in general, it would be very appropriate and interesting to gain further insights regarding their opinions on the impact of this unprecedented scenario. Whilst this can be done on a general level, the examination of tennis coaches' 
specific behaviors and experiences can assist in developing interventions based on real world experiences.

Previous studies have highlighted the importance of multicultural approaches to analyzing the impact of COVID-19 in Latin America and European countries [20]. Moreover, the long tradition of the sport of tennis in the Latin American region and in Spanish- and Portuguese-speaking European countries makes this sample particularly relevant. Therefore, the purpose of this paper was to study the perceptions of Spanish- and Portuguesespeaking tennis coaches working in Latin American and European countries regarding the impacts of the COVID-19 pandemic on their health, professional, and economic circumstances. It was hypothesized that, overall, the COVID-19 pandemic has had a significant impact on tennis coaches, both from a health and professional perspective. Furthermore, this impact has been greater on Latin American coaches regarding both their health and professional circumstances, therefore, these coaches, compared to European coaches, will perceive the pandemic more as a threat and as a period with fewer opportunities for educational and professional improvement.

\section{Materials and Methods}

\subsection{Study Design}

The study was a quantitative, descriptive cross-sectional study based on survey methodology [21].

\subsection{Sample}

The study sample consisted of 655 Spanish- and Portuguese-speaking tennis coaches working in Latin American $(n=219)$ and European $(n=436)$ countries (Table 1). Therefore, the selection criteria of participants of the coaches were, on the one hand, that they were working in a Latin American or European country and, on the other hand, that their language was Spanish or Portuguese. All coaches who spoke other languages, or who worked in regions other than those listed above, were excluded from the sample. Of the coaches who were part of the final sample, $88 \%(n=578)$ were men and $12 \%(n=77)$ were women. Regarding their experience as coaches, $25 \%(n=162)$ had less than 10 years of experience, $31 \%(n=202)$ had between 11 and 20 years of experience, and $44 \%(n=291)$ had more than 20 years of experience. As per the type of venue in which they worked, $29 \%(n=188)$ worked in public facilities and $71 \%(n=467)$ in private venues. Finally, with regards to their dedication to coaching, $70 \%(n=457)$ were full-time, while $30 \%(n=198)$ were part-time.

\subsection{Instrument}

An ad-hoc questionnaire was developed for data collection. The design and validation of the instrument consisted of four different stages. Firstly, the authors of the research individually carried out a review of the scientific literature and of the various guidelines published by the relevant tennis organizations to identify the different possible variables and to create an initial proposal of items and item definitions. Secondly, this initial proposal was shared among the authors in order to reach a consensus on the items identified and the definitions developed that formed the initial version of the instrument. Next, five qualified expert coaches, coach educators, tennis managers, and medical officers were asked to carry out a qualitative and quantitative evaluation by analyzing, evaluating, and proposing improvements to the items and definitions included in the initial version of the instrument. Based on these proposals, a final version of the instrument was designed. The questionnaire was divided in three sections: sociodemographic data, impact on health data, and professional impact data. This specific instrument was considered appropriate to assess the attitudes and perceptions of the tennis coaches in the sample due to its specific and practical application to the context and issues tennis coaches have faced during the pandemic. 
Table 1. Countries of origin of the tennis coaches who composed the study sample.

\begin{tabular}{cc}
\hline Country & Number of Coaches \\
\hline Argentina & 37 \\
Brazil & 22 \\
Chile & 3 \\
Colombia & 101 \\
Costa Rica & 3 \\
Ecuador & 2 \\
El Salvador & 2 \\
Spain & 426 \\
Guatemala & 14 \\
Honduras & 3 \\
Mexico & 14 \\
Panama & 1 \\
Paraguay & 1 \\
Peru & 1 \\
Portugal & 10 \\
Puerto Rico & 1 \\
Dominican Republic & 1 \\
Uruguay & 1 \\
Venezuela & 12 \\
\hline
\end{tabular}

The 20-item questionnaire assessed attitudes and perceptions on two levels (health and professional) and at different subcategories of each level. For the items of the professional category a Likert scale was used ( 1 = completely disagree; $2=$ mostly disagree; $3=$ undecided; $4=$ mostly agree; $5=$ completely agree). The internal validity of the questionnaire was assessed through test-retest reliability [22]. The questionnaire was administered to 20 coaches one month after having completed it for the first time. The reliability coefficient was calculated through the Pearson's correlation between the scores on the first and the second testing (Table 2).

Table 2. Categories and sub-categories included in the survey of the study.

\begin{tabular}{|c|c|c|c|}
\hline Category & Sub-Category & Item & $\begin{array}{c}\text { Test-Retest } \\
\text { Reliability (Pearson's r) }\end{array}$ \\
\hline \multirow[t]{2}{*}{ Health } & Infected & $\begin{array}{l}\text { Please indicate if you have been infected by } \\
\text { COVID-19. }\end{array}$ & 1 * \\
\hline & Quarantine & $\begin{array}{l}\text { Please indicate if you have been in quarantine due to } \\
\text { having direct contact with someone infected with } \\
\text { COVID-19. }\end{array}$ & 1 * \\
\hline \multirow{8}{*}{ Professional } & Economy & $\begin{array}{l}\text { From an economic point of view, to what degree has } \\
\text { COVID-19 negatively affected you? }\end{array}$ & $0.88 *$ \\
\hline & Number of players & $\begin{array}{l}\text { Compared to the previous period, during the } \\
\text { pandemic period, the number of players in my tennis } \\
\text { program has increased. }\end{array}$ & $0.84 *$ \\
\hline & Number of bookings & $\begin{array}{l}\text { Compared with the previous period, during the } \\
\text { pandemic period, the number of reservations } \\
\text { (face-to-face and online) of tennis courts has increased. }\end{array}$ & $0.79 *$ \\
\hline & Professional impact & $\begin{array}{l}\text { From a professional point of view, to what degree has } \\
\text { COVID-19 negatively affected you? }\end{array}$ & $0.75 *$ \\
\hline & Professional improvement & $\begin{array}{c}\text { The COVID-19 pandemic has been an opportunity to } \\
\text { improve professionally. }\end{array}$ & $0.89 *$ \\
\hline & Education & $\begin{array}{c}\text { The COVID-19 pandemic has allowed you to receive } \\
\text { more education. }\end{array}$ & $0.91 *$ \\
\hline & Educational offer & $\begin{array}{l}\text { During the pandemic, the professional tennis } \\
\text { education offer has increased. }\end{array}$ & $0.76^{*}$ \\
\hline & Threat & In general, you perceive the pandemic as a threat. & $0.93 *$ \\
\hline
\end{tabular}

\footnotetext{
* Significant correlation $(p \leq 0.05)$
} 


\subsection{Procedure}

Participant recruitment and data collection was undertaken over a one-month period from the end of January 2021. A convenience and snowball sampling techniques were used to recruit the tennis coaches. An online survey, a reliable tool which provides advantages for both participants and researchers [23], was placed on various social media platforms. Furthermore, due to the authors extended relationships with tennis coaches worldwide the survey was sent to the Directors of Coaches Education Departments of the National Associations of Spanish- and Portuguese-speaking countries for them to share with the coaches of their respective countries. Moreover, the researchers followed a snowball sampling process, directly inviting coaches who were part of their personal and professional circle and asking them to extend the invitation to their colleagues [24]. At the start of the online survey, the coaches were shown a description of the study and were informed about the confidentiality and voluntary nature of the research.

\subsection{Data Analysis}

The data obtained through the online questionnaire were exported to the Microsoft Excel program, where the data were processed to format them and make them suitable for analysis. Data analysis was carried out using the SPSS v26 statistical package. The Kolmogorov-Smirnov test was performed to check whether the variables were normally distributed. When deviations from normality were found for all variables, nonparametric statistics were used, employing the Mann-Whitney $U$ test to analyse quantitative variables and the Chi-square test for categorical variables. Effect size was measured using Cohen's d ( 0.20 small; 0.50 medium; 0.80 large) and Cramer's V ( 0.10 small; 0.30 medium; 0.50 large). The significance level was set at $p \leq 0.05$.

\section{Results}

\subsection{Impact on the Coaches' Health}

Figure 1 shows the results obtained on the variables related to the health category. As can be seen, $10.2 \%$ of coaches were infected and $20.8 \%$ were quarantined. Although no significant differences were found between continents in terms of the percentages of coaches who were infected, a clear trend can be observed showing that in Latin America $(13.2 \%)$ this percentage was higher than in Europe $\left(8.7 \% ; \mathrm{X}^{2}=3.25 ; p=0.07 ; \mathrm{V}=0.07\right)$. Regarding the percentage of coaches who had to be quarantined, in Latin America (25.6\%) this percentage was also significantly higher than in Europe $\left(18.3 \% ; X^{2}=4.62 ; p=0.03\right.$; $\mathrm{V}=0.08)$.

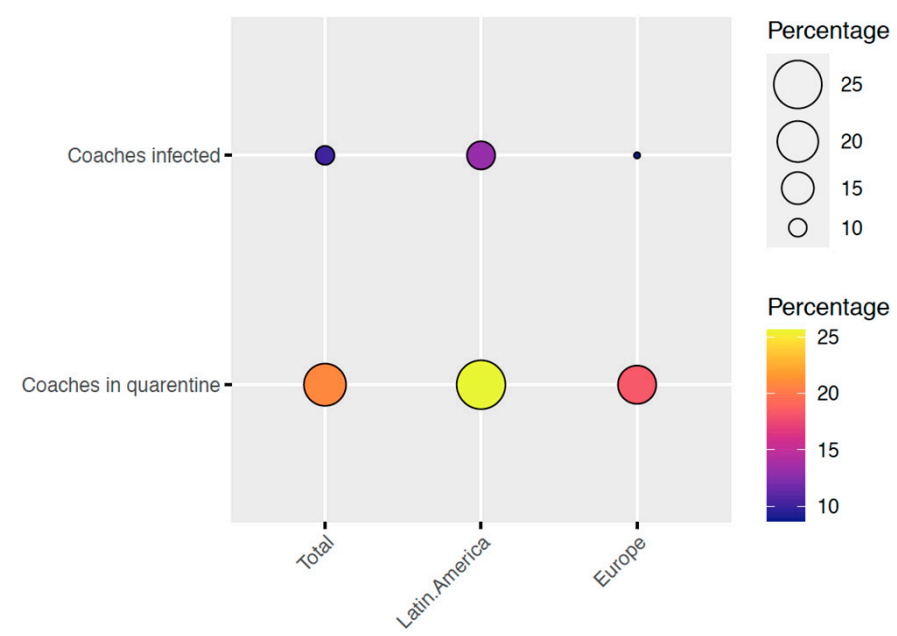

Figure 1. Differences in health category variables as a function of continent. 


\subsection{Impact on the Coaches' Profession}

With regards to professional impact, Latin American coaches indicated a higher negative economic impact (median $=4.00$ ) than European coaches $($ median $=3.00 ; \mathrm{z}=4.33$; $p<0.01 ; \mathrm{d}=0.34$ ). As per the increase in the number of players and court reservations during the pandemic period, no significant differences were found in the responses of coaches from both continents. Latin American coaches reported a greater negative affect from a professional point of view (median $=4.00$ ) than their European colleagues did (median $=3.00 ; \mathrm{z}=1.92 ; p=0.05 ; \mathrm{d}=0.16$ ). From a professional improvement standpoint, Latin American coaches viewed the pandemic as an opportunity to improve professionally significantly more $($ median $=5.00$ ) than the European coaches (median $=3.00 ; \mathrm{z}=9.53$; $p<0.01 ; \mathrm{d}=0.78$ ). Similarly, Latin American coaches also indicated more significantly that the pandemic had allowed them to become more educated as coaches (median $=5.00)$ in comparison to their European counterparts (median $=3.00 ; \mathrm{z}=10.08 ; p<0.01 ; \mathrm{d}=0.83$ ). In addition, Latin American coaches also indicated a greater increase in professional training offers (median $=4.00$ ) than European coaches (median $=3.00 ; \mathrm{z}=7.87 ; p<0.01 ; \mathrm{d}=0.64$ ). Finally, overall, European coaches perceived the pandemic as a threat (median $=5.00)$ more significantly than their Latin American colleagues (median $=4.00 ; \mathrm{z}=5.75 ; p<0.01$; $\mathrm{d}=0.44)$ (Table 3).

Table 3. Differences in professional category variables according to continent.

\begin{tabular}{|c|c|c|c|c|c|c|c|c|c|c|c|}
\hline & \multicolumn{3}{|c|}{ Total $(n=655)$} & \multicolumn{3}{|c|}{ Latin America $(n=219)$} & \multicolumn{3}{|c|}{ Europe $(n=436)$} & \multirow[b]{2}{*}{$p$} & \multirow[b]{2}{*}{ d } \\
\hline & M (SD) & $\begin{array}{l}\text { Median } \\
\text { (IR) }\end{array}$ & CI & $\mathrm{M}(\mathrm{SD})$ & $\begin{array}{l}\text { Median } \\
\text { (IR) }\end{array}$ & CI & $M(S D)$ & $\begin{array}{l}\text { Median } \\
\text { (IR) }\end{array}$ & CI & & \\
\hline Economy & $3.53(1.25)$ & $4.00(2.00)$ & $3.43-3.63$ & $3.83(1.17)$ & $4.00(2.00)$ & $3.67-3.99$ & $3.38(1.26)$ & $3.00(1.00)$ & $3.26-3.50$ & $<0.01 *$ & 0.34 \\
\hline $\begin{array}{l}\text { Number of } \\
\text { players }\end{array}$ & $2.98(1.36)$ & $3.00(2.00)$ & $2.88-3.09$ & $2.86(1.44)$ & $3.00(3.00)$ & $2.66-3.05$ & $3.05(1.32)$ & $3.00(2.00)$ & $2.92-3.17$ & 0.10 & 0.13 \\
\hline $\begin{array}{l}\text { Number of } \\
\text { bookings }\end{array}$ & $3.16(1.33)$ & $3.00(2.00)$ & $3.06-3.27$ & $3.10(1.45)$ & $3.00(2.00)$ & $2.90-3.29$ & $3.20(1.26)$ & $3.00(2.00)$ & $3.08-3.32$ & 0.54 & 0.12 \\
\hline $\begin{array}{l}\text { Professional } \\
\text { impact }\end{array}$ & $3.49(1.19)$ & $4.00(1.00)$ & $3.40-3.59$ & $3.61(1.22)$ & $4.00(2.00)$ & $3.44-3.77$ & $3.43(1.18)$ & $3.00(1.00)$ & $3.32-3.54$ & $0.05^{*}$ & 0.16 \\
\hline $\begin{array}{l}\text { Professional } \\
\text { improvement }\end{array}$ & $3.49(1.33)$ & $4.00(2.00)$ & $3.39-3.60$ & $4.17(1.08)$ & $5.00(2.00)$ & $4.02-4.31$ & $3.15(1.31)$ & $3.00(2.00)$ & $3.02-3.27$ & $<0.01 *$ & 0.78 \\
\hline Education & $3.50(1.36)$ & $4.00(2.00)$ & $3.40-3.61$ & $4.23(1.08)$ & $5.00(1.00)$ & $4.08-4.37$ & $3.13(1.33)$ & $3.00(2.00)$ & $3.00-3.26$ & $<0.01 *$ & 0.83 \\
\hline Educational offer & $3.28(1.29)$ & $3.00(2.00)$ & $3.18-3.38$ & $3.83(1.21)$ & $4.00(2.00)$ & $3.67-4.00$ & $3.00(1.23)$ & $3.00(2.00)$ & $2.88-3.12$ & $<0.01 *$ & 0.64 \\
\hline Threat & $3.95(1.16)$ & $4.00(2.00)$ & $3.86-4.04$ & $3.58(1.23)$ & $4.00(2.00)$ & $3.42-3.75$ & $4.14(1.09)$ & $5.00(2.00)$ & $4.03-4.24$ & $<0.01 *$ & 0.44 \\
\hline
\end{tabular}

$\%$ = percentages, $\mathrm{M}=$ means, $\mathrm{SD}=$ standard deviations, $\mathrm{IR}=$ interquartile range, $\mathrm{CI}=95 \%$ confidence intervals; ${ }^{*}$ Significant differences $(p \leq 0.05)$

\section{Discussion}

\subsection{Impact on the Coaches' Health}

Despite working in a social context where coaches constantly interact with other people, the percentage of coaches infected with COVID-19 reported by the sample of this study is similar to the percentage of infected people in general [25]. This could be a good indicator that the conditions under which tennis is played do not imply an added health risk for coaches. Therefore, it might be interesting to study what measures have been taken by coaches to reduce the risk of infection.

Regarding the differences between Latin American and European coaches in this aspect, although not significant, there is a trend that indicates that the number of coaches infected in Latin America was higher than in Europe. Similarly, the percentage of Latin American coaches who were forced to be confined was significantly higher than that of European coaches. These data coincide with those obtained by some previous studies that have analyzed the number of COVID-19 cases in Latin American and European countries (Spain and Italy), finding that the rate of virus replication in the first days of the epidemic was higher in Latin America than in Spain and Italy [20]. However, caution should be exercised when considering these data, as they fluctuate significantly depending on time and countries. 


\subsection{Impact on the Coaches' Profession}

Many sport organizations have suffered in all aspects of their operations due to the COVID-19 pandemic [26]. The results obtained in this study show that coaches have not been oblivious to these problems, indicating that the pandemic has negatively affected their profession and, subsequently, their finances. Furthermore, these problems were more evident among Latin American coaches, who agreed more strongly that the pandemic had negative economic consequences for them. The COVID-19 pandemic has impacted Latin America at a time of economic weakness and macroeconomic vulnerability [27], which is likely to have created more negative economic consequences for coaches in this region.

During the COVID-19 pandemic, athletes have experienced an interruption of their regular practices and competitions [28]. This disruption of sporting activities may influence the attraction, retention, and participation of players in any sport, in this case tennis. Coaches, both Latin American and European, were neutral about the increase in the number of players and court bookings after the pandemic. Although they did not disagree, they did not agree that there has been an increase, thus we can conclude that there has been a slight increase in players and court bookings, although it has not been very evident. Interestingly enough, this perception is different to the data obtained from surveys in the USA regarding the increase of racquets and balls shipments in the fourth quarter of 2020 [29] and the growth of tennis participation throughout the nation [30]. These positive trends have also been reported in the case of the UK, where data indicates that grassroots tennis enjoyed a boom in 2020 with an increase by eight per cent from 2019, due to the distanced nature of the sport [31].

The employment situation of many sports coaches has been considerably affected by the impact of the pandemic. Therefore, coaches expressed their concerns about aspects such as financial instability or job insecurity [32]. In the case of tennis, the results obtained in this work indicate that, indeed, the pandemic has negatively affected tennis coaches in general. Moreover, the professional impact has been more accentuated in Latin American coaches, who showed higher values of agreement regarding this negative professional impact than European coaches.

Previous studies have indicated that one of the consequences of the pandemic for sports coaches has been that coaches have had more time for professional development. In addition, coach developers have perceived an increase in their workload as the demand for coaches in training programs has increased [32]. The tennis coaches of this study expressed similar views, indicating that the pandemic had been an opportunity to train and improve professionally. In this context, it is worth noting the differences between the perceptions of Latin American and European coaches. While the Europeans were more neutral, the Latin American coaches mostly agreed that the pandemic had allowed them to improve their training, education, and professional development. It seems logical that with this increase in demand for training programs and activities for coaches, the offer should also increase. In this study, although the European coaches were more neutral, the Latin American coaches were more in agreement with the increase in the educational offering, which seems logical as they also perceived an increase in demand.

As indicated throughout this study, the consequences of the pandemic for tennis coaches have been quite dramatic, with negative health, economic, and social ramifications. It is therefore not surprising that coaches perceived the pandemic as a threat. However, it is noteworthy that, although the health and employment impact of the pandemic on European coaches has been lower than on their Latin American colleagues, they perceived the pandemic as a threat more significantly than their counterparts.

\section{Limitations, Practical Applications, and Future Research}

The present study has limitations that should be considered. The participant base was solely Spanish and Portuguese speaking, representing both European and Latin American cultures. However, since this paper is part of a broader research project which involves 
coaches from different nations worldwide, it was considered appropriate to select the coaches from these nations.

From a practical application perspective, COVID-19 is an unprecedented medical, human, and economic crisis. The psychological impact on individuals worldwide is not to be underestimated in these times of uncertainty, volatility, and potential danger. Coaches around the world have had their livelihoods "turned up-side-down" with work terminated, reduced, put on hold, or modified to comply with new health guidelines and regulations. There is a call to action for coaches to rise to these challenges and take check of their mental health. It is hoped that this paper assists in this process so that, when coaches exit the crisis, they do so with enhanced or new capabilities to embrace and thrive in what will be a new beginning. Most importantly, coaches should not hesitate to get professional help if required along this journey [33].

The results of this study also provide further directions for future research. As indicated by Hurley [34], the maintenance of some of the high-quality online coach training initiatives and knowledge-sharing could help coaches to maintain not only their own professional development but also solidify and strengthen any now-established new collaborations and friendships that the pandemic has enabled them to forge across their sports' community. Such moves could benefit their skillset as well as their wellbeing into the future. Research evaluating the approaches currently in place in this regard in order to ensure how best to achieve these aims into the future would also be welcomed.

\section{Conclusions}

As hypothesised, the COVID-19 pandemic has had a great impact on tennis coaches, both from a health and professional point of view. Regarding the differences between Latin American and European coaches, as expected, Latin American coaches suffered a greater impact from a health, economic, and professional point of view. However, contrary to what was hypothesised, they have seen the pandemic as an opportunity for professional improvement and professional education compared to European coaches. In addition, their perception of the pandemic as a threat has been significantly lower.

The year 2020 will long be remembered for the massive upheaval from the COVID-19 pandemic. The health, social, and economic shocks of the pandemic continue to reverberate around the world with no immediate end in sight. As we try to comprehend the enormity of recent events, a striking feature about COVID-19 has been the speed and exponential nature of a pandemic that has crippled and enveloped world economies and communities [35]. The scale of the repercussions has been breath-taking and cautions us against believing that a reversion to "what was" is possible [33].

Everyone that loves tennis has a great responsibility to transform the postponement of tennis play caused by the pandemic into an amazing opportunity. During these unprecedented times, the tennis world can use innovation strategies to accept this challenge, to promote, adapt, and improve our sport, and to celebrate the hope, benefits, and enjoyment of tennis play [9].

We are living in unprecedented times. The global uncertainty created by COVID-19 will continue to create a fluid and rapidly changing environment that will impact multiple areas. Therefore, all tennis stakeholders need to understand that the main priority is creating a safe and appropriate environment for all players. In this scenario, the tennis ecosystem should remain flexible and adaptable, learning from an active approach and listening to feedback from all those involved so that where changes are needed they can be implemented for the benefit of the game and its constituents [36].

Author Contributions: Conceptualization, M.C., J.R.-L., and R.M.-G.; Methodology, M.C., J.R.-L., and R.M.-G.; Formal Analysis, M.C. and J.R.-L.; Investigation, M.C. and R.M.-G.; Data Curation, M.C.; Writing-Original Draft Preparation, M.C. and J.R.-L.; Writing—Review \& Editing, M.C., J.R.-L., and R.M.-G.; Supervision, M.C.; Project Administration, M.C. All authors have read and agreed to the published version of the manuscript. 
Funding: This research received no external funding.

Institutional Review Board Statement: At the University of Valencia, the Ethics Committee stated: "If an opinion survey is to be carried out, on any topic or issue, professional situation, satisfaction with certain issues, etc., no authorisation from the Ethics Committee is required".

Informed Consent Statement: Informed consent was obtained from all subjects involved in the study.

Data Availability Statement: The data presented in this study are available on request from the corresponding author. The data are not publicly available due to privacy.

Acknowledgments: The authors wish to acknowledge the contributions of the International Tennis Federation's Education Department.

Conflicts of Interest: The authors declare no conflict of interest.

\section{References}

1. WHO Coronavirus (COVID-19) Dashboard. Available online: https:/ / covid19.who.int (accessed on 21 April 2021).

2. IOC President Bach Writes to Olympic Movement: Olympism and Corona-Olympic News. Available online: https://www. olympic.org/news/ioc-president-bach-writes-to-olympic-movement-olympism-and-corona (accessed on 21 April 2021).

3. ITF-ITF Global Tennis Report 2019: Overview. Available online: http://itf.uberflip.com/i/1169625-itf-global-tennis-report-20 19-overview/15? (accessed on 21 April 2021).

4. Evans, A.B.; Blackwell, J.; Dolan, P.; Fahlén, J.; Hoekman, R.; Lenneis, V.; McNarry, G.; Smith, M.; Wilcock, L. Sport in the Face of the COVID-19 Pandemic: Towards an Agenda for Research in the Sociology of Sport. Eur. J. Sport Soc. 2020, 17, 85-95. [CrossRef]

5. Faraji, S.; Ghayour Najafabadi, M.; Rostad, M.; Anastasio, A.T. The Effect of COVID-19 Quarantine on Physical and Social Parameters of Physical Education Providers and Youth Sport Coaches. WOR 2020, 67, 767-769. [CrossRef]

6. Oblinger-Peters, V.; Krenn, B. "Time for Recovery" or “Utter Uncertainty"? The Postponement of the Tokyo 2020 Olympic Games Through the Eyes of Olympic Athletes and Coaches. A Qualitative Study. Front. Psychol. 2020, 11, 610856. [CrossRef]

7. Taku, K.; Arai, H. Impact of COVID-19 on Athletes and Coaches, and Their Values in Japan: Repercussions of Postponing the Tokyo 2020 Olympic and Paralympic Games. J. Loss Trauma 2020, 25, 623-630. [CrossRef]

8. Roberts, R.J.; Lane, A.M. Mood Responses and Regulation Strategies Used During COVID-19 among Boxers and Coaches. Front. Psychol. 2021, 12, 624119. [CrossRef]

9. Crespo, M.; Jabaloyes, J. Something New? Innovation Post COVID-19. A Must for Tennis. ITF Coach. Sport Sci. Rev. 2021, 28 , 8-11. [CrossRef]

10. International Tennis Federation. Return to Tennis Guidelines. ITF Coach. Sport Sci. Rev. 2021, 28, 16-20. [CrossRef]

11. King, K.R. Professional Tennis's Constellational Response to COVID-19. Int. J. Sport Commun. 2020, 13, 8. [CrossRef]

12. Kowalik, Z.; Lewandowski, P. The Gender Gap in Aversion to COVID-19 Exposure: Evidence from Professional Tennis. PLoS ONE 2021, 16, e0249045. [CrossRef] [PubMed]

13. Parrish, C.; Otto, K.A.; Dodson, C. Talent Migration in NCAA Division I Tennis: An Exploratory Study. Sport Soc. 2020, 23, 1811-1826. [CrossRef]

14. Bonavolontà, V.; Cataldi, S.; Maci, D.; Fischetti, F. The Educational Relationship between Teachers and Young Tennis Players Continued During the Covid-19 Outbreak: Is the Online Teaching a New Start also for the University? In Bridges and Mediation in Higher Distance Education; Agrati, L.S., Burgos, D., Ducange, P., Limone, P., Perla, L., Picerno, P., Raviolo, P., Stracke, C.M., Eds.; Communications in Computer and Information Science; Springer International Publishing: Cham, Switzerland, 2021; Volume 1344, pp. 151-157, ISBN 978-3-030-67434-2.

15. Turner, M.; Beranek, P.; Rogers, S.L.; Nosaka, K.; Girard, O.; Cruickshank, T. Influence of the COVID-19 Pandemic on Mood and Training in Australian Community Tennis Players. Front. Sports Act. Living 2021, 3, 589617. [CrossRef] [PubMed]

16. Antonini Philippe, R.; Schiavio, A.; Biasutti, M. Adaptation and Destabilization of Interpersonal Relationships in Sport and Music during the Covid-19 Lockdown. Heliyon 2020, 6, e05212. [CrossRef]

17. Rahman, A.A.; Suherman, A.; Susilawati, D.; Putra, G.P. RADEC (Reading, Answering, Demonstrating, Explaining, and Creating) in LMS to Teach Tennis without Field Practicing. Univers. J. Educ. Res. 2020, 8, 5433-5442. [CrossRef]

18. Bradbury, T.; Galloway, C. New Zealand tennis's match point moment. Sport and the Pandemic: Perspectives on Covid-19's Impact on the Sport Industry. In Sport and the Pandemic: Perspectives on Covid-19's Impact on the Sport Industry; Pedersen, P.M., Ruihley, B.J., Li, B., Eds.; Routledge: New York, NY, USA, 2020; pp. 51-58.

19. Slater, K.; Watkins, J. Tennis players' responses to Covid-19 and the global pandemic's impact on professional tennis governance. In Sport and the Pandemic: Perspectives on Covid-19's Impact on the Sport Industry; Pedersen, P.M., Ruihley, B.J., Li, B., Eds.; Routledge: New York, NY, USA, 2020; pp. 146-156.

20. Caicedo-Ochoa, Y.; Rebellón-Sánchez, D.E.; Peñaloza-Rallón, M.; Cortés-Motta, H.F.; Méndez-Fandiño, Y.R. Effective Reproductive Number Estimation for Initial Stage of COVID-19 Pandemic in Latin American Countries. Int. J. Infect. Dis. 2020, 95, 316-318. [CrossRef] 
21. Thomas, J.R.; Nelson, J.K.; Silverman, S.J. Research Methods in Physical Activity, 7th ed.; Human Kinetics: Champaign, IL, USA, 2015; ISBN 978-1-4504-7044-5.

22. McIntire, S.A.; Miller, L.A. Foundations of Psychological Testing; McGraw-Hill: Boston, MA, USA, $1999 ;$ p. 448.

23. Braun, V.; Clarke, V.; Boulton, E.; Davey, L.; McEvoy, C. The Online Survey as a Qualitative Research Tool. Int. J. Soc. Res. Methodol. 2020, 1-14. [CrossRef]

24. Sadler, G.R.; Lee, H.-C.; Lim, R.S.-H.; Fullerton, J. Research Article: Recruitment of Hard-to-Reach Population Subgroups via Adaptations of the Snowball Sampling Strategy: Hard-to-Reach Populations. Nurs. Health Sci. 2010, 12, 369-374. [CrossRef]

25. Noh, J.; Danuser, G. Estimation of the Fraction of COVID-19 Infected People in U.S. States and Countries Worldwide. PLoS ONE 2021, 16, e0246772. [CrossRef]

26. Sanderson, J.; Brown, K. COVID-19 and Youth Sports: Psychological, Developmental, and Economic Impacts. Int. J. Sport Commun. 2020, 13, 313-323. [CrossRef]

27. Comisión Económica para América Latina y el Caribe (CEPAL)—Informe Sobre el Impacto Económico en América Latina y el Caribe de la Enfermedad por Coronavirus (COVID-19). Available online: https://www.casede.org/index.php/bibliotecacasede-2-0/salud-y-seguridad/558-informe-sobre-el-impacto-economico-en-america-latina-y-el-caribe-de-la-enfermedadpor-coronavirus-covid-19 (accessed on 21 April 2021).

28. Kelly, A.L.; Erickson, K.; Turnnidge, J. Youth Sport in the Time of COVID-19: Considerations for Researchers and Practitioners. Manag. Sport Leis. 2020, 1-11. [CrossRef]

29. Strong Fourth Quarter Contributes to Annual Increase in US Tennis Racquet and Ball Shipments-Sports Marketing Surveys. Available online: https: / www.sportsmarketingsurveys.com/strong-fourth-quarter-contributes-to-annual-increase-in-us-tennisracquet-and-ball-shipments (accessed on 21 April 2021).

30. Tennis Industry Shows Strength in Face of Coronavirus Pandemic. Available online: https://www.usta.com/en/home/staycurrent/national/tennis-industry-shows-strength-in-face-of-coronavirus-pandemic.html (accessed on 21 April 2021).

31. Grassroots Tennis Gains Unlikely Boost from Coronavirus as Participation Grows. Available online: https://www.heraldscotland. com/sport/uk-sport/19190081.grassroots-tennis-gains-unlikely-boost-coronavirus-participation-grows/ (accessed on 21 April 2021).

32. Callary, B.; Brady, A.; Kiosoglous, C.; Clewer, P.; Resende, R.; Mehrtens, T.; Wilkie, M.; Horvath, R. Making Sense of Coach Development Worldwide During the COVID-19 Pandemic. Int. J. Sport Commun. 2020, 13, 575-585. [CrossRef]

33. Young, J.A.; Pearce, A.J. The Warrior within: Fortifying Mental Health in the COVID-19 Pandemic. ITF Coach. Sport Sci. Rev. 2021, 28, 4-7. [CrossRef]

34. Hurley, O.A. Sport Cyberpsychology in Action during the COVID-19 Pandemic (Opportunities, Challenges, and Future Possibilities): A Narrative Review. Front. Psychol. 2021, 12, 621283. [CrossRef] [PubMed]

35. Hooper, N.; Southward, J.; Aitken, D. What Happens Next? Co. Dir. 2020, 36, 16-19. [CrossRef]

36. Santilli, L.; Crespo, M. Editorial. ITF Coach. Sport Sci. Rev. 2020, 81, 2. [CrossRef] 